\title{
Statistical Optimization and Kinetic Studies of Enhanced Bioremediation of Crude Oil - Contaminated Marine Water Using Combined Adsorption-Biostimulation Strategy
}

\author{
${ }^{* 1}$ SAMUEL E. AGARRY \\ Biochemical and Bioenvironmental Engineering Laboratory, \\ Department of Chemical Engineering, Delta State University, Abraka, \\ P. M. B. 22, Oleh Campus, NIGERIA. \\ E-mail:sam_agarry@yahoo.com; agarryse@delsu.edu.ng;Tel: +2348055529705
}

\begin{abstract}
The objectives of this study were to investigate and evaluate through Taguchi orthogonal experimental design the effects of amendment agents as well as the optimization and kinetics of enhanced bioremediation of crude oil-contaminated marine water using combined adsorption-biostimulation strategy. The amendment agents are organic fertilizer, slow release inorganic NPK fertilizer, commercial activated carbon and Tween 80. Bioremediation of weathered Escravos crude oil (WECO)-contaminated marine water was studied for four weeks in ten plastic buckets open system. The oil-contaminated marine water in nine of the buckets was each amended with the amendment agents according to Taguchi's (L9) orthogonal array of four factors and three levels and the tenth un-amended bucket served as control (natural bioattenuation). Results showed that the amendment agents had relative significant influence on the enhancement of WECO-marine water bioremediation. The optimum amendment agent conditions were determined as follows: organic fertilizer $30 \mathrm{~g}$, inorganic slow release NPK fertilizer $4 \mathrm{~g}$, activated carbon $30 \mathrm{~g}$, and Tween $80,1.5 \mathrm{~g}$. Under these optimum conditions, the optimum percentage of crude oil biodegradation achieved was $98.25 \%$. Bioremediation kinetic data of WECO fitted well to the first-order kinetic model. The combined adsorptionbiostimulation strategy (using the amendment agents) resulted in higher biodegradation rate constant, $k\left(0.0443-0.1183\right.$ day $\left.^{-1}\right)$ and lower biodegradation half-life, $t_{1 / 2}$ (5.86 - 15.6 days) of the WECO biodegradation than the natural bioattenuation with lower $k\left(0.0144\right.$ day $\left.^{-1}\right)$ and higher $t_{1 / 2}$ (48.8 days). Therefore, the amendment agents have effective potential application as a tool for combined adsorption-biostimulation strategy in the remediation of crude oilcontaminated aquatic environment. (C) JASEM
\end{abstract}

http://dx.doi.org/10.4314/jasem.v21i1.7

Keywords: Biodegradation; Bioremediation; Amendment agents; Crude oil; Kinetics; Optimization.

Marine oil pollution has elicited more public concern than any other waste or spilt material. It is estimated that about 600,000 tons of oil enter the marine environment from natural seeps (Hazen et al., 2015) while more than 2 million tons of oil enters marine environments from ships and other sea-based human activities annually (Zahed et al., 2011). The crude oil which is an extremely complex mixture of aliphatic and aromatic hydrocarbons have been found to cause chronic sub-acute toxicological effect, alter population dynamics and disrupt tropic interactions and the structure of natural communities within ecosystems (Bejarano and Michel, 2010). Bioremediation is an ecologically acceptable technique that exploits the diverse degradation abilities of microorganisms to efficiently convert complex organic components of crude petroleum to harmless products by mineralization. Enhanced bioremediation which covers a wide form of techniques may involve bioaugmentation and/or biostimulation. Biostimulation is the addition of nutrients or electron acceptors/electron donors to biostimulate naturally occurring microbial species as to enhance the biodegradation of target pollutant or contaminant (Chien et al., 2008; Agarry et al., 2013). According to the report of Barrios San Martín (2011) and Padayachee and Lin (2011) supplementation of nutrient is essential for enhancing bacterial growth and degradation activity.

The positive effects of inorganic nutrient such as NPK fertilizers (Kumari et al., 2016), urea fertilizer (Chikere et al., 2016), oleophilic fertilizers (Rosenberg et al., 1996) as well as organic nutrient such as animal wastes-derived organic fertilizer (Agarry et al., 2013; Obiakalaije et al., 2015) and agricultural crop/plant residues-derived organic fertilizer (Agarry et al., 2013; Hamzah et al., 2016) in the biostimulation of petroleum hydrocarbon degradation in soil and marine sediments/shorelines/beach have been extensively demonstrated. Few workers have reported the positive effective use of inorganic nutrient (Hassanshahian et al., 2014), slow release fertilizer (Gertler et al., 2009), guano organic fertilizer that contains uric acid (Knezevich et al., 2007), cow dung (Umanu et al., 2013) and agro-industrial solid waste date (Elmahdi et al., 2014) in enhancing the E-mail: sam_agarry@yahoo.com; agarryse@delsu.edu.ng; Tel: +2348055529705 
bioremediation of open sea water system (mesocosm) polluted with crude oil or petroleum hydrocarbons. Furthermore, the positive effects of variety of surfactants such as anionic, cationic, zwitter-ionic, non-ionic surfactants as well as biosurfactants on hydrocarbon degradation or removal have been reported (Lai et al., 2009; Tsai et al., 2009; Couto et al., 2010; Zhu and Aitken, 2010; Thavasi et al., 2011). However, in some cases, the negative effect of surfactant has also been reported (Avramova et al., 2008). Surfactants are a group of amphiphilic chemicals that contain both hydrophilic and hydrophobic parts in their molecular structure (Mao et al., 2015). The high toxicity of petroleum hydrocarbons to microbes and the rapid dispersion of bacteria often restrict the use of microbes (bioaugmentation) for highly contaminated natural ecosystem (Tagger et al., 1983). Thus, amendment with adsorbents or sorbent material can help to overcome these two problems (Vasilyeva et al., 2006). However, combined method of adsorption and bioremediation is in recent time gaining attention as a means of remediation referred to as adsorptive bioremediation (Agarry et al., 2015). The addition of activated carbon (AC) as well as biochar is currently being investigated as an in situ technology to remediate contaminated soil and sediments (Ghosh et al., 2011; Meynet et al., 2012; Agarry et al., 2015). Nevertheless, information on the effective use of nutrients, surfactants and adsorbent as amendment agents in the remediation of oil-contaminated marine/seawater (open systems) is still very scanty and the literature is still inconclusive on the amendment agents' conditions that are sufficient for different environment.

Bioremediation being a multi-variable process is dependent on optimizing the factors which have effect on the microbial growth and biodegradation of pollutant (Cappello et al., 2015). The conventional method of optimization through varying the level of one factor at a time (OFAT) over a certain range and holding the rest of the test factors constant is a cumbersome, time, cost and labour consuming work (Das Mohapatra et al. 2009; Mandal et al., 2015). As a solution, the concept of design of experiments (DOE) which is a statistical form of design of experiments have been introduced which helps to reduce the number of experiments to large extent, evaluate the effect of several factors, makes optimization easy, helps in building the models, and achieving the optimum conditions (Mehta et al., 2016). In the recent times, the use of Taguchi orthogonal array (OA) design of experiment is gaining popularity in determining the effect of factors and the optimal conditions of factors. Taguchi method being one of the powerful optimization techniques, is a simple mathematical and statistical tool involving a system of tabulated designs (arrays) that allows a maximum number of main effects to be estimated in an unbiased (orthogonal) fashion with a minimum number of experimental runs (CastorenaCortes, 2009). This method establishes the relationship between variables and operational conditions (Roy 2001). The modeling that is performed essentially relates signal-to-noise ratio to the control variables in a 'main effect only' approach. This methodology has been successfully applied to optimize the production of many industrial enzymes such as laccase (Nandal et al., 2013), xylanase (Mandal et al., 2015) and amidase (Mehta et al., 2016). It has also been applied in the bioadsorption of pollutants such as heavy metals from aqueous solutions (Kumar et al., 2013; Agarry and Ogunleye, 2015) and in the production of polyhroxybutyrate (Tripathi and Srivastava, 2011). There are very few reports on the use of this method in studying bioremediation/biodegradation process of organic chemicals/petroleum hydrocarbons in soil (Kulkarni, 2014; Ravanipour et al., 2015). However, the use of this method in studying bioremediation process of water polluted or contaminated with organic chemicals/petroleum hydrocarbons has not been reported in the literature. Therefore, the objectives of this work were to investigate and evaluate through Taguchi orthogonal array of experimental design the effects of amendment agents as well as the optimization and kinetics of enhanced crude oil bioremediation in marine water using combined adsorption-biostimulation strategy. The amendment agents are organic fertilizer (fertilizer composed or compounded of cattle dung, pig dung and poultry droppings), slow release inorganic NPK fertilizer, commercial activated carbon (adsorbent/biocarrier) and Tween 80 (non-ionic surfactant).

\section{MATERIALS AND METHODS}

Sample Collection: Natural marine water samples were collected from a sea in the Niger-Delta region of Nigeria. The Escravos light crude oil (API, 35.3, gravity SG; 0.85 , sulphur (wt \%); 0.15 , viscosity (cSt at $40^{\circ} \mathrm{C}$ ); 3.28) was obtained from one of the oil prospecting company in the Niger-Delta region of Nigeria. Osmocote slow release inorganic NPK fertilizer (14:14:14) (made up of $8.20 \%$ ammoniacal nitrogen, $5.80 \%$ nitrate nitrogen, $14 \%$ available phosphate and $14 \%$ soluble potash) (Scotts International B.V.,Geldermalsen, the Netherlands) used as inorganic nutrient was purchased from an agro-chemical store in Benin-City, Nigeria. The animal dung wastes which consisted of cattle dung, pig dung and poultry droppings (mixture of which was used as organic fertilizer) were obtained from a commercial farm in Benin, Nigeria. Commercial activated carbon was obtained from a chemical store in Benin, Nigeria.

Sample Preparation: The Escravos crude oil was weathered by exposure to the atmospheric condition for two weeks with occasional stirring after which it 
was stored for further use. Each of the animal wastes was air dried and homogenized, thereafter passed through a 2-mm (pore size) sieve and stored in a polyethylene bag at ambient temperature.

Sample Characterization: The marine water and animal wastes samples were characterized for total organic carbon (TOC), total nitrogen $(\mathrm{N})$, total phosphorus, moisture content, $\mathrm{pH}$ and total hydrocarbon degrading bacteria (THDB) according to standard methods (APHA, 2005). The samples $\mathrm{pH}$ was determined using the $\mathrm{pH}$ meter that have been calibrated with buffer solutions of $\mathrm{pH} 4.0,7.0$ and 10.0 , respectively. Sample $\mathrm{pH}$ was determined according to the modified method of McLean (1982). Five gram (or $5 \mathrm{ml}$ ) of the sample was weighed and transferred into $100 \mathrm{ml}$ beaker after which $10 \mathrm{ml}$ of distilled water was added. It was stirred vigorously for 15 seconds, allowed to stand for $30 \mathrm{~min}$ and the $\mathrm{pH}$ meter probe was inserted and the $\mathrm{pH}$ value recorded.

Total organic carbon was determined using the Walkley and Black wet combustion method modified by Nelson and Sommers (1982). In this method, $1 \mathrm{~g}$ of sample was weighed into a 250-ml Erlenmeyer conical flask. Then, $10 \mathrm{ml}$ of $0.16 \mathrm{M}$ potassium dichromate solution was added into the content of the flask and the flask carefully shaken to allow for thorough mixture of the flask contents. Under a fume hood, $20 \mathrm{ml}$ of concentrated sulfuric acid was added to the contents of the flask, mixed gently and then allowed to stand for $5 \mathrm{~min}$. Thereafter, distilled water was added to the contents in the flask such that the final volume was approximately $125 \mathrm{ml}$ and then mixed by swirling the flask gently. The flask and its content was allowed to cool and return to room temperature after 30 minutes. Later, 5 or 6 drops of Phenanthroline complex was added and immediately titrated with $1.0 \mathrm{M}$ ferrous sulfate solution. As the titration proceeded, the solution takes on a green colour that later changed abruptly to reddish-brown when the endpoint of the titration was reached. A blank titration was carried out using the same procedure as above but without sample. The organic carbon (OC) was calculated as in Eq. (1):

$O C, \%=\frac{10 \times\left[1-\left(V_{1} / V_{0}\right)\right] \times 0.039}{M_{R}}$

Where $V_{1}=$ volume of sulphuric acid used in titration of sample; $V_{0}=$ volume of sulphuric acid used in titration of blank test; $M_{R}=$ mass of oven-dry sample (mg).

Total nitrogen was determined by the semi-microKjeldahl method (Bremner and Mulvaney, 1982). According to this method, the dried and grinded animal dung sample of about $0.2 \mathrm{~g}$ was transferred into a digestion flask (kjeldahl flask) and $10 \mathrm{ml}$ of sulfuric acid was added and the flask swirled until the acid was thoroughly mixed with the sample. Thereafter, $2 \mathrm{~g}$ of the catalyst mixture was added and the digestion mixture heated at $400^{\circ} \mathrm{C}$ until a clear solution was obtained. The cleared solution was further boiled gently for up to $5 \mathrm{~h}$ so that the sulfuric acid condenses about $1 / 3$ of the way up to the neck of the flask. After completion of the digestion step, the flask was allowed to cool and $20 \mathrm{ml}$ of distilled water was added and the flask swirled to bring any insoluble material into suspension. The contents of the digestion flask was then transferred to the steamed-out distillation apparatus. Five (5) $\mathrm{ml}$ of boric acid was transferred into a $250 \mathrm{ml}$ conical flask and the flask was placed under the condenser of the distillation apparatus in such a way that the end of the condenser dipped into the solution. Then, $20 \mathrm{ml}$ of sodium hydroxide was allowed to run slowly through the funnel of the apparatus into the distillation chamber. Thereafter, a few drops of mixed indicator was added to the distillate $(100 \mathrm{ml})$ obtained and titrated with sulfuric acid to a violet endpoint. For the marine water sample, $300 \mathrm{ml}$ of sample was poured into the kjeldahl flask and a few boiling chips or glass beads were added and thereafter the contents transferred to the distillation apparatus. The total nitrogen, $\mathrm{N}(\mathrm{mg} / \mathrm{kg}$ ) was calculated as in Eq. (2):

$$
N=\frac{V_{1}-V_{0} \times c\left(H^{+}\right) \times M_{N} \times 100}{M_{S} \times M_{R}}
$$

Where $V_{1}=$ volume sulphuric acid used in titration of sample; $V_{0}=$ volume of sulphuric acid used in titration of blank test; $c\left(H^{+}\right)=$concentration of hydrogen in sulphuric acid in mols/litre; $M_{N}=$ molar mass of nitrogen in gram $/$ mole $=14 ; M_{S}=$ mass of test sample; $M_{R}=$ dry residue expressed as $\mathrm{g} / 100 \mathrm{~g}$.

Total phosphorus was determined by sodium carbonate fusion and molybdenum antimony-ascorbic acid colorimetric method (Olsen and Sommers, 1982). According to this method, $5 \mathrm{~g}$ of the sample was weighed into $250 \mathrm{ml}$ Erlenmeyer conical flask and one teaspoon of activated charcoal and $100 \mathrm{ml}$ $0.5 \mathrm{M}$ sodium hydrogen carbonate $\left(\mathrm{NaHCO}_{3}\right)$ solution were then added. The flask was shaken for 30 minutes in mechanical shaker. Thereafter, the contents in the flask was filtered through a Whatman No.1 filter paper. Ten (10) $\mathrm{ml}$ aliquot of the filtrate was transferred into a $50 \mathrm{ml}$ volumetric flask and 10 $\mathrm{ml}$ of ammonium molybdate solution as well as a little quantity of distilled water was added and then shaken very well. One (1) $\mathrm{ml}$ of $\mathrm{SnCl}_{2}$ solution was then added and the volume was made up to $50 \mathrm{ml}$ with distilled water and shaken well. This was then allowed to stand for 5 to $15 \mathrm{~min}$ to allow a blue 
colour to develop after which the absorbance was taken at $660 \mathrm{~nm}$ using a DR/2010 HACH Portable Data Logging Spectrophotometer. The phosphorus concentration in the given sample was obtained using the standard curve.

The population densities of total hydrocarbondegrading bacteria (THDB) in the samples were determined in duplicates on modified mineral salt agar (MSA) using the spread plate or pour plate method (Cruickshank et al., 1980). Ten-fold serial dilution was done. One (1) gram of the sample was weighed and introduced into the first three test tubes containing normal saline. Each of the tube was shaken thoroughly to allow for proper mixing of the mixture. One (1) $\mathrm{ml}$ was drawn by means of a pipette and introduced into another test tube containing $9 \mathrm{ml}$ of normal saline to give a $10^{-1}$ dilution. The sample was diluted serially up to $10^{-5}$. All the test tubes were covered with cotton wool. Thereafter, $0.1 \mathrm{ml}$ aliquots of the appropriate dilution was inoculated onto a duplicate petri dish containing modified mineral salt agar (MSA). A sterile filter paper (Whatman No 1) was saturated with crude oil (the oil served as a sole source of carbon) and was then placed inside the cover of the petri dish, closed and inverted. The petri dish was thereafter incubated at $28^{\circ} \mathrm{C}$ for $5-8$ days. Microbial colonies were counted, screened, and pure cultures obtained by replica plating. Identification was based on the taxonomic schemes and descriptions of Bergey's Manual of Determinative Bacteriology (Holt et al., 1994).

\section{Sample Treatment: Taguchi Design and Bioremediation of Crude Oil - Contaminated Marine Water}

To obtain maximum or optimum yield of crude oil biodegradation, amendment agents optimization was performed using the Taguchi orthogonal array of design of experiment, L9 $\left(3^{4}\right)$ selected from the design module of Stat-Ease Design Expert 10. This design requires nine experiments with three parameters at each of these three levels. Four amendment agents (factors) which consists of organic fertilizer, slow release inorganic NPK fertilizer, commercial activated carbon and Tween 80 and their three effective levels were chosen as presented in Table 1.

Table 1: Process parameters and their levels

\begin{tabular}{lllll}
\hline Symbol & Factors & \multicolumn{3}{c}{ Levels } \\
\cline { 3 - 5 } & & 1 & 2 & 3 \\
\hline $\mathrm{A}$ & Organic fertilizer $(\mathrm{g})$ & 20 & 30 & 40 \\
$\mathrm{~B}$ & Slow release inorganic NPK fertilizer $(\mathrm{g})$ & 3 & 4 & 5 \\
$\mathrm{C}$ & Commercial activated carbon $(\mathrm{g})$ & 20 & 30 & 40 \\
$\mathrm{D}$ & Tween $80(\mathrm{~g})$ & 1 & 1.5 & 2 \\
\hline
\end{tabular}

The organic fertilizer (A), slow release inorganic NPK fertilizer (B), activated carbon (C) and Tween 80 (D) were assigned to the $1^{\text {st }}, 2^{\text {nd }}, 3^{\text {rd }}$ and $4^{\text {th }}$ column of L9 array, respectively. The three levels of the factors were set as low, intermediate and high. A total of nine experiments were used to investigate the effects of the four amendment agents or factors (Table 2). Ten plastic bucket open system with $15 \mathrm{~L}$ capacity were used as bioreactors for the study and into each of the plastic bucket bioreactor was poured one (1) litre of natural marine water and thereafter contaminated with $100 \mathrm{ml}$ of weathered Escravos crude oil (WECO). The four amendment agents (organic fertilizer, slow release inorganic NPK fertilizer, commercial activated carbon and Tween
80) was each added to the contents in nine plastic bucket bioreactor labelled L1 to L9 according to the constructed Taguchi orthogonal matrix (Table 2). The tenth un-amended plastic bucket bioreactor served as control (natural bioattenuation). The contents in each bioreactor were thoroughly mixed to allow for aerobic condition. All the plastic bucket bioreactors were incubated for four weeks at ambient temperature. All the experiments were carried out in triplicates. Samples from the experimental and control set-ups were taken at intervals of 7 days and analyzed for total petroleum hydrocarbon (TPH) so as to be able to monitor the kinetics of crude oil biodegradation.

Table 2: Experimental layout using an $L_{9}\left(3^{4}\right)$ Taguchi orthogonal array

\begin{tabular}{lllll}
\hline Experimental Run & \multicolumn{4}{c}{ Main Factors (Bioremediation Amendment Agent) } \\
\cline { 2 - 5 } & A & B & C & D \\
\hline L1 & 1 & 1 & 1 & 1 \\
L2 & 1 & 2 & 2 & 2 \\
L3 & 1 & 3 & 3 & 3 \\
L4 & 2 & 1 & 2 & 3 \\
L5 & 2 & 2 & 3 & 1 \\
L6 & 2 & 3 & 1 & 2 \\
L7 & 3 & 1 & 3 & 2 \\
L8 & 3 & 2 & 1 & 3 \\
L9 & 3 & 3 & 2 & 1 \\
Control & - & - & - & - \\
\hline
\end{tabular}


Sample Analysis: The TPH was analysed by first extracting the residual crude oil from both the experimental and control samples using n-hexane: dichloromethane solvent systems (1:1) and was quantified gravimetrically (Yveline et al., 1997; Agarry et al., 2013) and spectrophotometrically (Adesodun and Mbagwu, 2008; Agarry et al., 2013). Five milliliter of hexane: dichloromethane solvent system was added to the sample broth solutions and shaken vigorously for $5 \mathrm{~min}$ to extract the residual crude oil. The extract was filtered and filtrate centrifuged at $2500 \mathrm{rpm}$. Two different layers were formed- the upper organic phase layer and the lower medium layer. The upper organic phase layer contained the biodegraded crude oil. The organic phase layer was collected into a pre-weighed beaker using separating funnel. The process was repeated in triplicate and the combined organic phase layer was allowed to evaporate to dryness at room temperature and the beaker and its content was weighed after which the residual oil was obtained by difference in mass. Also, the organic phase extract (filtrate) was diluted by taking $1 \mathrm{ml}$ of the extract into $50 \mathrm{ml}$ of hexane. The absorbance of this organic solution was measured spectrophotometrically at a wavelength of $400 \mathrm{~nm}$ with HACH DR/2010 Spectrophotometer using n-hexane as blank. The TPH was estimated with reference to a standard curve derived from fresh crude oil of different concentration diluted with nhexane. Percent degradation (D) was calculated using Eq. (3):

$\mathrm{D}=\frac{T P H_{i}-T P H_{r}}{T P H_{i}} \times 100$

Where $\mathrm{TPH}_{i}$ and $\mathrm{TPH}_{r}$ are the initial and residual $\mathrm{TPH}$ concentrations, respectively.

Kinetics of Bioremediation: Information on the kinetics of bioremediation is of great importance because it characterizes the pollutant concentration remaining at any time and permit prediction of the level likely to be present at some future time (Agarry et al., 2013). Biodegradation rate of organic compounds by microorganisms is often described by the first-order kinetic equation (Eq. (4)) (Agarry et al., 2013):

$$
\ln \frac{T P H_{r(t)}}{T P H_{i}}=-k t
$$

Where $\mathrm{TPH}_{i}$ and $T P \mathrm{H}_{r(t)}$ are initial TPH concentration and residual TPH concentration at time, $t$ respectively, and $k$ is the biodegradation rate constant. The biodegradation (or biological) half-life is the time taken for a substance to lose half of its amount (Agarry et al., 2013). Biodegradation halflives are needed for describing the transformation of pollutants (Matthies et al., 2008; Agarry et al., 2013).

Biodegradation half-life times $\left(t_{1 / 2}\right)$ are calculated by Eq. (5) (Kuhan and Gupta, 2009; Agarry et al., 2013):

$t_{1 / 2}=\frac{\ln 2}{k}$

Where $k$ is the biodegradation rate constant $\left(\right.$ day $\left.^{-1}\right)$.

Statistical Analysis: Analysis of Variance (ANOVA) being a statistically based objective decision making tool was used to determine the significance of each factor while signal to noise ratio $(\mathrm{S} / \mathrm{N})$ was used in deciding the optimum levels of the factors. Signal to Noise $(\mathrm{S} / \mathrm{N})$ ratio is a performance measure designed by Taguchi and it selects the factor levels that maximize this ratio (Agarry and Ogunleye, 2015). The term signal represents the quality characteristic while noise is a measure of the variability (as measured by the variance) of the characteristics (Agarry and Ogunleye, 2015). The $\mathrm{S} / \mathrm{N}$ equation (Highest - is - best) used for the characteristics (percentage TPH reduction) to be optimized is given in Eq. (6):

$S / N=\frac{-10 \log \left(\sum_{i=1}^{n} 1 / y_{i, n}\right)}{n}$

$\mathrm{n}=$ number of tests in a trial

\section{RESULTS AND DISCUSSION}

Physico-chemical and Microbiological Characterization: The determined physical, chemical and microbiological parameter values of the marine water samples and animal wastes are presented in Table 3.

Table 3: Physical, chemical and microbiological properties of marine water and animal wastes

\begin{tabular}{lcccc}
\hline Parameter & Marine water & Cattle dung & Pig dung & Poultry droppings \\
\hline Organic Carbon (\%) & $12.25 \pm 0.02$ & $27.6 \pm 0.03$ & $29.4 \pm 0.01$ & $25.7 \pm 0.02$ \\
Total Nitrogen (\%) & $5.47 \pm 0.03$ & $2.80 \pm 0.01$ & $3.67 \pm 0.02$ & $3.10 \pm 0.02$ \\
Carbon: Nitrogen & $1: 2.24$ & $10: 1$ & $8: 1$ & $8.3: 1$ \\
Phosphorus (\%) & $1.10 \pm 0.01$ & $0.19 \pm 0.02$ & $0.25 \pm 0.01$ & $0.39 \pm 0.02$ \\
pH & $7.2 \pm 0.2$ & $7.7 \pm 0.1$ & $7.9 \pm 0.1$ & $7.3 \pm 0.2$ \\
Moisture (\%) & - & $7.9 \pm 0.2$ & $8.1 \pm 0.1$ & $7.0 \pm 0.2$ \\
THDB (cfu/g) & $3.1 \pm 0.8 \times 10^{6} \mathrm{cfu} / \mathrm{ml}$ & $3.4 \pm 3.7 \times 10^{7}$ & $4.2 \pm 4.1 \times 10^{7}$ & $4.9 \pm 2.9 \times 10^{7}$ \\
\hline
\end{tabular}

The water sample characterization revealed that the nutrient (NPK) requirements for an efficient biodegradation process are not fulfilled. These elements were then added in the form of inorganic and organic fertilizer to provide the proper nutrients required for the bioremediation process. The 
hydrocarbon degrading bacterial types identified in the marine water samples were mainly Bacteroidetes, Alphaproteobacteria and Cyanobacteria while those species identified in the animal wastes were mainly Escherichia coli, Staphylococcus species, Salmonella species, Bacillus species, Lactobacillus species,
Flavobacterium species, Methanobacterium species and Pseudomonas species.

Biodegradation of Weathered Escravos Crude Oil: Main Effects of Amendment Agents: After the 9 runs of the Taguchi orthogonal array design and one control were performed, the experimental results obtained are presented in Table 4.

Table 4: Experimental $L_{9}\left(3^{4}\right)$ orthogonal array and the experimental results

\begin{tabular}{lllllllll}
\hline Experimental Run & \multicolumn{9}{c}{ Main Factors } & \multicolumn{3}{c}{ \% TPH Reduction } \\
\cline { 2 - 9 } & A & B & C & D & 1 & 2 & 3 & Average \\
\hline L1 & 1 & 1 & 1 & 1 & 90.00 & 89.77 & 89.51 & 89.76 \\
L2 & 1 & 2 & 2 & 2 & 96.70 & 96.80 & 96.00 & 96.50 \\
L3 & 1 & 3 & 3 & 3 & 89.80 & 90.25 & 91.30 & 90.45 \\
L4 & 2 & 1 & 2 & 3 & 94.77 & 95.30 & 93.88 & 94.65 \\
L5 & 2 & 2 & 3 & 1 & 97.90 & 97.60 & 98.14 & 97.88 \\
L6 & 2 & 3 & 1 & 2 & 91.50 & 91.00 & 91.49 & 91.33 \\
L7 & 3 & 1 & 3 & 2 & 88.00 & 87.50 & 88.50 & 88.00 \\
L8 & 3 & 2 & 1 & 3 & 90.22 & 90.00 & 90.44 & 90.22 \\
L9 & 3 & 3 & 2 & 1 & 87.00 & 86.85 & 86.79 & 86.88 \\
Control & - & - & - & - & 51.55 & 51.60 & 51.65 & 51.60 \\
\hline
\end{tabular}

As presented in Table 4, It was observed that on day 28 ( $4^{\text {th }}$ week $)$, TPH had decreased in all the plastic bioreactors. In control bioreactor, natural bioattenuation resulted in $38.6 \%$ of TPH reduction. Umanu et al. (2013), Elmahdi et al. (2014) and Latinwo and Agarry (2015) have correspondingly showed that natural bioattenuation removed $22.99 \%$ of crude oil in lagoon water after 70 days, $14.7 \%$ of Libyan crude oil in sea water after 28 days and $40 \%$ of Bonny light crude oil in lagoon water after 42 days remediation periods, respectively. The efficiency of bioremediation is a function of the microbial viability in the natural ecological system (Joo et al., 2008; Agarry et al., 2013) and their viability is also dependent on some factors such as nutrient availability. As seen in Table 4, the percent TPH reduction due to amendment agents in experimental runs L1 to L9 (i.e. combined adsorptionbiostimulation strategy) was much higher (ranging from 86.88 to $97.88 \%$ ) than the percent TPH reduction in control bioreactor not subjected to amendment (natural bioattenuation) in the same 28 days remediation period. These results indicated that the combined addition of nutrients (organic fertilizer and slow release inorganic NPK fertilizer), adsorptive/biocarrier agent (commercial activated carbon) and surfactants (Tween 80) enhanced the rate of crude oil biodegradation (i.e. percent TPH reduction). In an orthogonal experimental design, the effect of each factor at the respective levels could be separated out (Zhou et al., 2010; Koh et al., 2013). Thus, in order to estimate the effect of factor A (organic fertilizer) on the average value of response variable (\% TPH reduction), sum of the average three observed response at level 1 of factor A was divided by 3 to obtain the average response at level 1 of factor A. The average responses at level 2 and 3 were obtained in a similar manner. The estimated main effects of the amendment agents or factors at the assigned levels on TPH reduction are depicted in Table 5.

Table 5:.Estimated factor effects on percent TPH reduction at different factor levels

\begin{tabular}{|c|c|c|c|}
\hline \multirow[t]{2}{*}{ Factors } & \multicolumn{3}{|c|}{ Levels } \\
\hline & 1 & 2 & 3 \\
\hline Organic fertilizer (A) & 92.24 & 94.62 & 88.37 \\
\hline Slow release inorganic & 90.80 & $94.87^{*}$ & 89.55 \\
\hline NPK fertilizer (B) & & & \\
\hline $\begin{array}{l}\text { Commercial activated carbon } \\
\text { (C) }\end{array}$ & 90.44 & 92.68 & 92.11 \\
\hline Tween 80 (D) & 91.51 & 91.94 & 91.77 \\
\hline
\end{tabular}

*Optimum level

The percent TPH reduction levels were found to be very much dependent on the amendment agents. Higher percent TPH reduction of $94.62 \%, 94.87 \%$, $92.68 \%$ and $91.94 \%$ were observed up to level 2 of organic fertilizer, slow release inorganic NPK fertilizer, commercial activated carbon and Tween 80 , respectively, and above these values the percent TPH reduction decreased. Organic fertilizer, slow release inorganic NPK fertilizer, commercial activated carbon and Tween 80 had higher effects in level 2 on percent TPH reduction. The estimated individual factor's effect on percent TPH reduction is shown in Figure 1 

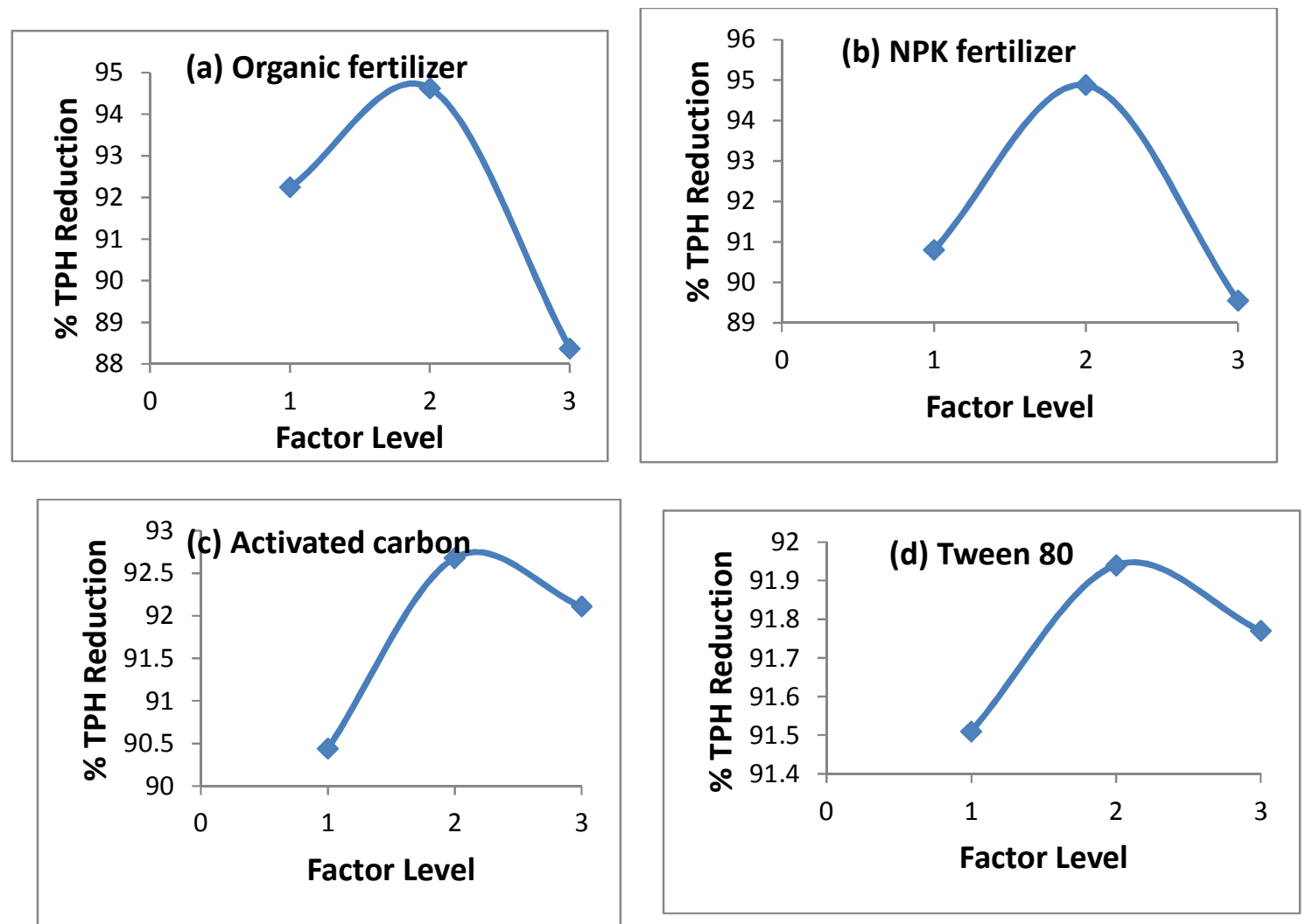

Fig 1: Estimated factor effects as a function of factor level on percent TPH reduction in WECO (a) Organic fertilizer (b) Slow release NPK fertilizer (c) Activated carbon (d) Tween 80

Figure 1(a) shows the effects of organic fertilizer (factor A) on the biodegradation of WECO. As shown in Figure 1(a), it was observed that at the range of 20 to $40 \mathrm{~g}$ of organic fertilizer, the percent TPH reduction increased from $92.24 \%$ to $94.62 \%$ as the amount of organic fertilizer was increased from 20 to $30 \mathrm{~g}$ and thereafter decreased to $88.37 \%$ as the amount of organic fertilizer was increased from 30 to $40 \mathrm{~g}$. This observation is in agreement with the observation of Umanu et al. (2014) in their use of cow dung for crude oil biodegradation in lagoon water. The percent TPH reductions at level 1 to level 3 (i.e. 20, 30 and $40 \mathrm{~g}$ ) are higher than the percent TPH reductions obtained in control bioreactor (natural bioattenuation). This observation indicates that the use of organic fertilizer enhanced the TPH reduction in crude oil-contaminated marine water. Similar observations have been reported for the use of organic fertilizer (of different forms) which include animal waste such as cow dung (Umanu et al., 2014; Obiakalaije et al., 2015; Chikere et al., 2016), poultry droppings/dung (Obiakalaije et al., 2015; Chikere et al., 2016), goat dung (Agarry et al., 2010; Obiakalaije et al., 2015), pig dung (Agarry et al., 2013), reptile waste such as uric acid based waste or guano fertilizer (Knezevich et al., 2007) and agricultural crop/plant residue like peanut hull powder (Xu and Lu, 2010), spent mushroom (Garcia-Delgado et al., 2015) in the bioremediation of soil and sediment contaminated with petroleum hydrocarbon/crude oil. The effects of slow release inorganic NPK fertilizer (factor B) on percent TPH reduction is shown in Figure 1 (b). At the range of 3 to $5 \mathrm{~g}$, the percent TPH reduction also increased from $90.80 \%$ to $94.87 \%$ as the amount of slow release inorganic NPK fertilizer was increased from 3 to $4 \mathrm{~g}$ and thereafter decreased to $89.55 \%$ as the amount of inorganic fertilizer was increased from 4 to $5 \mathrm{~g}$. This observation is in agreement with our earlier report on enhanced bioremediation of soil artificially contaminated with Bonny light crude oil using factorial design of experiments (Agarry and Ogunleye, 2012a) as well as on enhanced bioremediation of soil artificially contaminated with spent engine oil using BoxBehnken design of experiment (Agarry and Ogunleye, 2012b). This observation is also in agreement with the previous findings of Chaineau et al. (2005) and Chaillan et al. (2006) who reported the negative effects of high nutrients on biodegradation of petroleum hydrocarbons. Gertler et al. (2009) have reported the observation of eutrophication in the biodegradation of petroleum hydrocarbon in sea water contained in basins (mesocosm) with the use of few millimolars of slow release fertilizer (made up of both ammonium and nitrate) and that as a result of this eutrophication, a significant decrease of $\mathrm{pH}$ and production of highly toxic nitrite occurred. According to Gertler and his co-workers, the dosage of nutrients 
is a major problem for offshore marine bioremediation. The intrusion of oil into a marine system provides a substantial surplus of carbon for microbial growth. However, low availability of nutrients such as nitrogen and phosphorus can limit microbial growth and thus oil degradation (Hazen et al., 2015) while high nutrient concentration may be toxic for marine biota and cause eutrophication and red tide (Zahed et al., 2010). Also, the percent TPH reductions at level 1 to level 3 (i.e. 3,4 and $5 \mathrm{~g}$ ) are higher than the percent TPH reductions obtained in control bioreactor (natural bioattenuation). This observation indicates that the use of slow release inorganic NPK fertilizer enhanced the TPH reduction in crude oil-contaminated marine water. Similar observations have been reported for the use of inorganic fertilizer (nutrients) of different types such as nitrogen/nitrates and phosphorus (Nikolopoulou et al., 2013), NPK fertilizer (Cappelo et al., 2015; Hamzah et al., 2016; Kumari et al., 2016) and urea fertilizer (Chikere et al., 2016) in the bioremediation of soil and sediment contaminated with petroleum hydrocarbon/crude oil as well as the use of inorganic nutrient (Hassanshahian et al., 2014) for the biodegradation of crude oil in sea water. Figure 1 (c) shows the effects of commercial activated carbon (factor C) on percent TPH reduction. It could be observed that the percent TPH reduction generally increased from 90.40 to $92.11 \%$ with increment in the amount of commercial activated carbon from 20 to 40 $\mathrm{g}$ used in this study. This observation is in agreement with our earlier report on the adsorptive bioremediation of soil artificially contaminated with Bonny light crude oil (Agarry et al., 2015). Nevertheless, as shown in Figure 1(c), the maximum percent TPH reduction of $92.68 \%$ was obtained with the use of $30 \mathrm{~g}$ of commercial activated carbon and above this value it decreased. These percent TPH reductions at level 1 to level $3(20,30$ and $40 \mathrm{~g})$ are higher than the percent TPH reduction obtained in control bioreactor (natural bioattenuation). This observation indicates that the presence of commercial activated carbon enhanced the TPH reduction in crude oil-contaminated marine water. Similar observations have been reported for the use of activated carbon/activated charcoal in the bioremediation of soil and sediment contaminated with petroleum hydrocarbon/crude oil (Semenyuk et al., 2014; Agarry et al., 2015). The observed enhancement may be as a result of the fact that the applied activated carbon performed the task of adsorbing oil as well as providing a matrix for oildegrading microorganisms while at the same time improved the oxygen, nutrient and hydrocarbon mass transfer in the marine water (Gertler et al., 2009). In fact, both processes are linked, because the oil bound to the activated carbon (adsorbent) surface acts as a carbon and energy source for oil-degrading microorganisms. The effects of Tween 80 (factor D) on the percent TPH reduction is as shown in Figure 1(d). It was observed that the percent TPH reduction marginally increased from 91.51 to $91.77 \%$ with increase in the amount of Tween 80 from 1 to $2 \mathrm{~g}$. However, the maximum percent TPH reduction of 91.94\% was obtained with the use of $1.5 \mathrm{~g}$ of Tween 80 and above this value it decreased. This observation is in agreement with our earlier report on enhanced bioremediation of soil artificially contaminated with kerosene using statistical design of experiment (Agarry et al., 2012). The percent TPH reductions observed at level 1 to level 3 (i.e. 1, 1.5 and $2 \mathrm{~g}$ ) are higher than the percent TPH reduction obtained in control bioreactor (natural bioattenuation). This observation indicates that the Tween 80 surfactant enhanced the TPH reduction in crude oilcontaminated marine water. Similar observations have been reported for the use of surfactants in the biodegradation of petroleum hydrocarbons in soil and sediments (Lai et al., 2009; Tsai et al., 2009; Couto et al., 2010; Zhu and Aitken, 2010). The enhancement brought about by the surfactant may be due to the fact that it increased the bioavailability of hydrocarbon due to its ability to increase dissolution into the aqueous phase and cell surface hydrophobicity and thus changed the affinity between the microbial cell and hydrocarbon (Hadiyat and Tachibana, 2013).

The $\mathrm{S} / \mathrm{N}$ ratios were computed for percent $\mathrm{TPH}$ reduction in each of the 10 trial conditions as presented in Table 8.

Table 8: Taguchi experimental layout and the calculated signal-to-noise ratio (S/N)

\begin{tabular}{llllll}
\hline Experimental Run & \multicolumn{6}{c}{ Main Factors (Bioremediation Amendment Agent) } & S/N Ratio (dB) \\
\cline { 2 - 7 } & A & B & C & D & \\
\hline L1 & 1 & 1 & 1 & 1 & 4.92 \\
L2 & 1 & 2 & 2 & 2 & 5.02 \\
L3 & 1 & 3 & 3 & 3 & 4.93 \\
L4 & 2 & 1 & 2 & 3 & 5.00 \\
L5 & 2 & 2 & 3 & 1 & 5.05 \\
L6 & 2 & 3 & 1 & 2 & 4.94 \\
L7 & 3 & 1 & 3 & 2 & 4.89 \\
L8 & 3 & 2 & 1 & 3 & 4.93 \\
L9 & 3 & 3 & 2 & 1 & 4.87 \\
Control & - & - & - & - & 4.12 \\
\hline
\end{tabular}


Since the experimental design is orthogonal, the effect of each factor on the $\mathrm{S} / \mathrm{N}$ ratio at different levels can be separated out. The average effect of the factors (at the assigned levels) on the percent TPH reductions are expressed in terms of mean $\mathrm{S} / \mathrm{N}$ ratios and are summarized in Table 9.

Table 9: Mean signal-to-noise (S/N) ratio response for percent TPH reduction

\begin{tabular}{lcccc}
\hline Factors & \multicolumn{3}{c}{ Levels } & Maximum - Minimum $(\delta)$ \\
\cline { 2 - 5 } & 1 & 2 & 3 & \\
\hline Organic fertilizer (A) & 4.96 & 5.00 & 4.90 & 0.10 \\
Slow release inorganic NPK fertilizer (B) & 4.94 & 5.00 & 4.91 & 0.09 \\
Commercial activated carbon (C) & 4.93 & 4.96 & 4.96 & 0.03 \\
Tween 80 (D) & 4.95 & 4.96 & 4.95 & 0.01 \\
\hline
\end{tabular}

Note: Total mean $(\mathrm{S} / \mathrm{N}) \bar{\eta}=14.85$

Individually at level stage, all the considered four factors have highest effect in level 2, which is clearly visualized in Figure 2. Figure 2 shows the $\mathrm{S} / \mathrm{N}$ ratio plot where the dashed line is the value of the total mean of the $\mathrm{S} / \mathrm{N}$ ratio. Basically, the larger the $\mathrm{S} / \mathrm{N}$ ratio, the better is the percent $\mathrm{TPH}$ reduction rate.

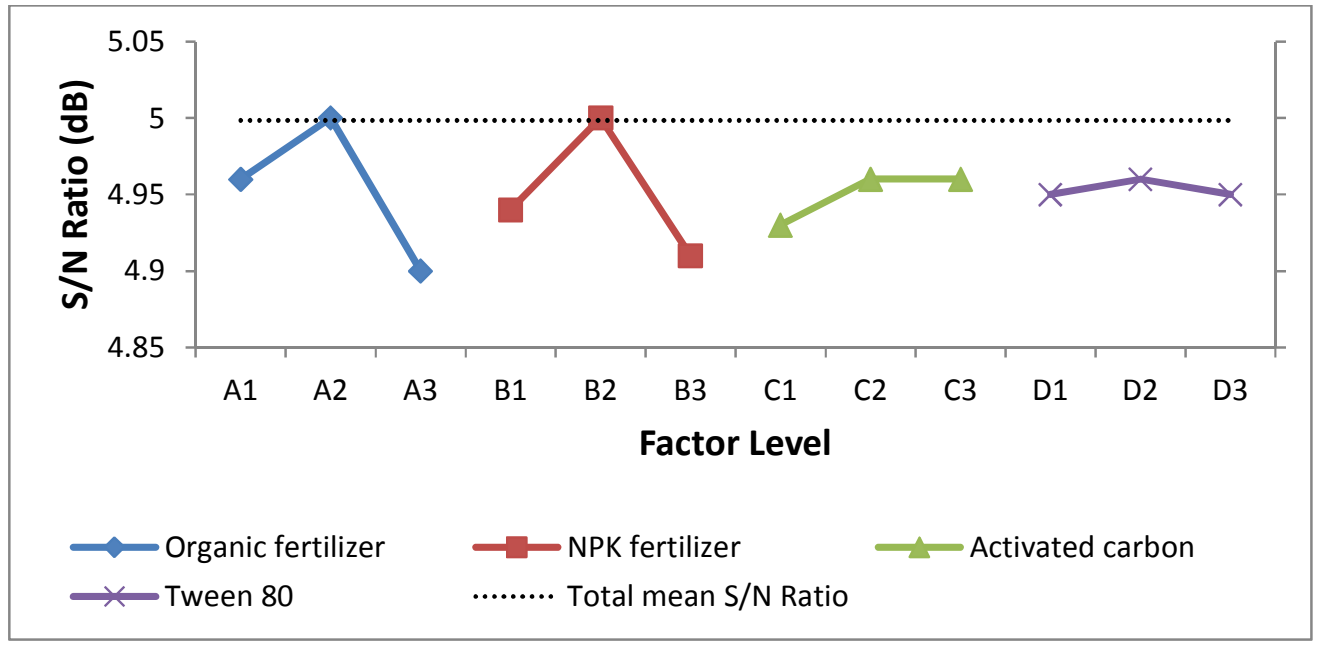

Fig 2: S/N ratio plot for percent TPH reduction at different factor level

The relative influence of each factor is represented by the difference between the maximum and minimum $\mathrm{S} / \mathrm{N}$ ratios of the levels. This difference or range is represented by $\delta$ value. Determination of these $\delta$ values is important for ranking the factors from the strongest to the weakest effect on the percent TPH reduction, where a high $\delta$ value would indicate that the factor had a strong impact on the output signal response (Peace, 1993; Koh et al., 2013). The larger the difference, the stronger is the relative influence. Among the factors studied, organic fertilizer shows stronger influence than the other factors since its $\delta$ value was the highest. This was followed by slow release inorganic NPK fertilizer, activated carbon and Tween 80 , respectively.

The experimental data were fitted to a factorial regression main effects model (Eq. (4)) containing 8 linear terms using the Design-Expert (version 10) software to derive the equation for crude oil biodegradation in marine water.

$Y=\beta_{o}+\beta_{1} A_{1}+\beta_{2} A_{2}+\beta_{3} B_{1}+\beta_{4} B_{2}+\beta_{5} C_{1}+\beta_{6} C_{2}+\beta_{7} D_{1}+\beta_{8} D_{2}$ (4)
Where $\beta_{o}$ is the value of the fixed response at the centre point of the design; $\beta_{1}, \beta_{2}, \beta_{3}, \beta_{4}, \beta_{5}, \beta_{6}$ are linear coefficients; respectively; $\mathrm{A}, \mathrm{B}, \mathrm{C}$ and $\mathrm{D}$ are the levels of independent amendment variables. The significance of each coefficient in the equation was determined by F-test and $P$-values. F-test indicated that all the factors considered in the experimental design are statistically significant $(P<0.05)$ at the 95 per cent confidence level. The regression equation obtained after analysis of variance gives the percentage of total petroleum hydrocarbon reduction (crude oil removal) as a function of the amendment variables at low and high level: organic fertilizer, slow release inorganic NPK, commercial activated carbon and Tween 80. All terms regardless of their significance are included in the following Eq. (5):

$\mathrm{Y}=91.74+0.50 \mathrm{~A}_{1}+2.88 \mathrm{~A}_{2}-0.94 \mathrm{~B}_{1}+3.13 \mathrm{~B}_{2}-$ $1.30 \mathrm{C}_{1}+0.94 \mathrm{C}_{2}-0.23 \mathrm{D}_{1}+0.20 \mathrm{D}_{2}$

Where A is organic fertilizer concentration, B is slow release inorganic NPK concentration; $\mathrm{C}$ is commercial activated carbon; and D is Tween 80 
concentration while 1 and 2 represents the low and high levels of the amendment variables or factors. To test the fit of the model, the regression equation and
$R^{2}$ were evaluated as presented in Table 10 .

Table 10: ANOVA for the factorial main effects model fitting to the WECO biodegradation data

\begin{tabular}{|c|c|c|c|c|c|c|c|}
\hline Factor & "SS & "DF & "MS & F-value & $P$-value & Remarks & $\%$ Contribution \\
\hline Model & 114.20 & 6 & 19.03 & 130.96 & 0.0076 & Significant & - \\
\hline Organic fertilizer (A) & 59.76 & 2 & 29.88 & 205.59 & 0.0048 & Significant & 52.19 \\
\hline NPK fertilizer (B) & 46.30 & 2 & 23.15 & 159.29 & 0.0062 & Significant & 40.44 \\
\hline Activated carbon (C) & 8.14 & 2 & 4.07 & 28.00 & 0.0345 & Significant & 7.11 \\
\hline Tween 80 (D) & 0.29 & 2 & 0.15 & - & - & Significant & 0.26 \\
\hline Error & 0 & 0 & 0 & & & & \\
\hline Correlation Total & 114.50 & 8 & & & & & \\
\hline
\end{tabular}
SS = Sum of squares; DF = Degree of freedom; MS = Mean Square

As presented in Table 10, the model F-value of 130.96 implies the model is significant. There is only a 0.76 per cent chance that a model F-value, this large could occur due to noise alone. The low probability value (0.0076) indicates that the model is significant. The value of $R^{2}=0.9975$ indicates a high degree of correlation between the observed and predicted values. The correlation coefficient $(\mathrm{R}=0.9987)$, suggests that more than $99.87 \%$ of the variance is attributable to the variables and indicated a high significance of the model. Thus, $0.13 \%$ of the total variance cannot be explained by the model. The fitted model is considered adequate if the F-test is significant $(P<0.05)$. The analysis of variances (ANOVA) factorial model demonstrated that the model was highly significant, as was evident from the very low probability $(P<0.0076)$ of the $\mathrm{F}$-test. The Predicted $R^{2}$ value of 0.9486 is in reasonable agreement with the Adjusted $R^{2}$ value of 0.9898 . Generally a model can be considered reasonably reproducible if its coefficient of variation $(\mathrm{CV})$ is not greater than $10 \%$. Hence, the low value of $\mathrm{CV}=$ $0.42 \%$ obtained indicates a high precision and reliability of the experiments. The percent contributions of the factors are presented in Table 10. Percent contribution indicates the relative power of a factor to reduce variation (Esme, 2009; Agarry and Ogunleye, 2015). For a factor with a high percent contribution, a small variation will have a great influence on the performance. According to Table 10, organic fertilizer was found to be the major factor affecting the percent TPH reduction $(52.19 \%)$, while slow release inorganic NPK fertilizer was found to be the second ranking factor $(40.44 \%)$ and relatively followed by commercial activated carbon $(7.11 \%)$ and Tween $80(0.26 \%)$, respectively. Interestingly, the ranking sequence of significant factors (amendment agents) obtained from ANOVA was consistent with the ranking of influential factors in Table 9. That is, crude oil biodegradation was mostly and positively influenced by organic fertilizer relatively followed by slow release inorganic NPK fertilizer and activated carbon.

Estimation and Evaluation of Kinetic Parameter and Half-Life: First-order kinetics model equation (Eq. (4)) was fitted to the biodegradation kinetic data as to determine the rate of crude oil biodegradation in response to the different amendment agents' remediation treatments. The results in Table 6 as indicated by the high $R^{2}$ (=0.99) showed that the biodegradation dynamics of crude oil in marine water fitted well to the first-order kinetic model, hence, the bioremediation of crude oil in marine water can well be described by the first-order kinetic model. Table 6 show the estimated biodegradation rate constants $(k)$ and the corresponding coefficient of determination ( $R^{2}$ ) obtained from fitting of the model as well as the corresponding biodegradation half-lives $\left(t_{1 / 2}\right)$ obtained using Eq. (5) 
Table 6: Taguchi experimental layout and the estimated biodegradation rate constant and half-life

\begin{tabular}{ccccccccccc}
\hline Run & \multicolumn{9}{c}{ Main Factors } & \multicolumn{9}{c}{ Rate Constant $\left(k\right.$, day $\left.^{-1}\right)$} & & $R^{2}$ & $t_{1 / 2}$ (days) \\
\cline { 2 - 11 } & A & B & C & D & 1 & 2 & 3 & Average & & \\
\hline L1 & 1 & 1 & 1 & 1 & 0.0488 & 0.0489 & 0.0487 & 0.0488 & 0.9961 & 14.2 \\
L2 & 1 & 2 & 2 & 2 & 0.1059 & 0.1058 & 0.1057 & 0.1058 & 0.9968 & 6.55 \\
L3 & 1 & 3 & 3 & 3 & 0.0610 & 0.0616 & 0.0616 & 0.0614 & 0.9992 & 11.3 \\
L4 & 2 & 1 & 2 & 3 & 0.0816 & 0.0811 & 0.0809 & 0.0812 & 0.9987 & 8.54 \\
L5 & 2 & 2 & 3 & 1 & 0.1180 & 0.1182 & 0.1186 & 0.1183 & 0.9994 & 5.86 \\
L6 & 2 & 3 & 1 & 2 & 0.0743 & 0.0748 & 0.0744 & 0.0745 & 0.9972 & 9.30 \\
L7 & 3 & 1 & 3 & 2 & 0.0472 & 0.0476 & 0.0468 & 0.0472 & 0.9973 & 14.7 \\
L8 & 3 & 2 & 1 & 3 & 0.0489 & 0.0494 & 0.0490 & 0.0491 & 0.9989 & 14.1 \\
L9 & 3 & 3 & 2 & 1 & 0.0446 & 0.0442 & 0.0441 & 0.0443 & 0.9998 & 15.6 \\
Control & - & - & - & - & 0.0140 & 0.0142 & 0.0144 & 0.0142 & 0.9977 & 48.8 \\
\hline
\end{tabular}

As seen in Table 6, the biodegradation rate constant ( $k$ ) and the corresponding biodegradation half-life ( $\left.t_{1 / 2}\right)$ varied with each amendment agents treatment (experimental run L1 to L9). In general, the biodegradation rate constant, $k$ (that ranges from 0.0443 to 0.1183 day $^{-1}$ ) due to combined adsorptionbiostimulation remediation strategy (L1 - L9) is higher than the rate constant $\left(k=0.0144\right.$ day $\left.^{-1}\right)$ due to natural bioattenuation (control). While the corresponding biodegradation half-life, $t_{1 / 2}$ (that ranges from 5.86 to 15.6 days) due to combined adsorption-biostimulation remediation strategy (L1 L9) is lower than the half-life $\left(t_{1 / 2}=48.8\right.$ days $)$ due to natural bioattenuation (control). Similar observations have been reported for the treatment of petroleum hydrocarbons in soil and sediments (Zahed et al., 2011; Agarry et al., 2013; Mohajeri et al., 2013). It is to be noted that the higher is the biodegradation rate constants, the higher or faster is the rate of biodegradation and consequently the lower is the biodegradation half-life time (Agarry et al., 2013). Half-life has been recommended as a principle standard to decide whether a substance should be categorized as persistent or not (Mohajeri et al., 2013). Substances with a half-life of more than 40 days are considered persistent. The results indicated that the biodegradation half-life time of crude oil subjected to natural bioattenuation (in the control bioreactor) was more than 40 days and this was reduced to very low half-life time using the combined adsorption-biostimulation strategy. Therefore, WECO can be considered to be a persistent organic chemical substance in water and its biodegradation can be enhanced using combined adsorptionbiostimulation strategy. The estimated individual factor (amendment agent) effects on the biodegradation rate constant of crude oil biodegradation at different levels are presented in Table 7.
Table 7: Estimated factor effects on biodegradation rate constant at different levels

\begin{tabular}{llll}
\hline Factors & \multicolumn{3}{c}{ Levels } \\
\cline { 2 - 4 } & 1 & 2 & 3 \\
\hline Organic fertilizer (A) & 0.0720 & $0.0913^{*}$ & 0.0469 \\
NPK fertilizer (B) & 0.0591 & $0.0911^{*}$ & 0.0601 \\
Activated carbon (C) & 0.0575 & $0.0771^{*}$ & 0.0756 \\
Tween 80 (D) & 0.0705 & $0.0758^{*}$ & 0.0639 \\
\hline
\end{tabular}

*Optimum level

As presented in Table 7, it was observed that at the range of 20 to $40 \mathrm{~g}$ of organic fertilizer, the biodegradation rate constant increased from 0.0720 to 0.0913 day $^{-1}$ as the amount of organic fertilizer was increased from 20 to $30 \mathrm{~g}$ and thereafter decreased to 0.0469 day $^{-1}$ as the amount of organic fertilizer was increased above 30 (i.e. to $40 \mathrm{~g}$ ). The biodegradation rate constant of TPH biodegradation generally increased from 0.0591 to 0.0601 day $^{-1}$ with increase in the amount of slow release inorganic NPK fertilizer from 3 to $5 \mathrm{~g}$. However, the highest biodegradation rate constant $\left(0.0911 \mathrm{day}^{-1}\right)$ was obtained using $4 \mathrm{~g}$ of slow release inorganic NPK fertilizer and above this amount, the rate constant decreased. Similarly, it was observed that the biodegradation rate constant generally increased from 0.0575 to $0.0756 \mathrm{day}^{-1}$ as the amount of commercial activated carbon increased from 20 to $40 \mathrm{~g}$. This observation is in agreement with our earlier report on the adsorptive bioremediation of soil artificially contaminated with Bonny light crude oil (Agarry et al., 2015). Nevertheless, the maximum biodegradation rate constant $\left(0.0771 \mathrm{day}^{-1}\right)$ was obtained with the use of $30 \mathrm{~g}$ of commercial activated carbon and above this amount, it decreased. Finally, it was also observed that the biodegradation rate constant of crude oil biodegradation or TPH reduction increased from 0.0705 to 0.0758 day $^{-1}$ with increase in the amount of Tween 80 from 1 to $1.5 \mathrm{~g}$ and then decreased to $0.0639 \mathrm{day}^{-1}$ as the amount of Tween 80 was increased above $1.5 \mathrm{~g}$ (i.e. to $2 \mathrm{~g}$ ). Table 8 shows that the biodegradation rate of crude oil in marine water under the influence of these factors is higher than the rate of biodegradation due to natural bioattenuation. The estimated biodegradation half-life of crude oil subjected to the different amendment treatment at the optimum level 
(level 2) is 7.59, 7.61, 8.99 and 9.14 days for organic fertilizer, slow release inorganic NPK fertilizer, commercial activated carbon and Tween 80, respectively; while for the control (natural bioattenuation), the biodegradation half-life is 48.8 days. The results indicated that the estimated biodegradation half-lives of crude oil is different for each amendment agent treatment.

Statistical Optimization of Crude Oil Biodegradation: The results of experiments as presented in Table 4 revealed that the maximum percent TPH reduction $(97.88 \%)$ with the corresponding highest biodegradation rate constant $\left(k=0.1183\right.$ day $\left.^{-1}\right)$ and minimum biodegradation half-life $\left(t_{1 / 2}=5.86\right.$ days $)$ occurred in experimental run L5 when experimental conditions were combination of the levels A2, B2, $\mathrm{C} 3$, and D1; that is: organic fertilizer $(30 \mathrm{~g})$, slow release inorganic NPK fertilizer (4 g), commercial activated carbon $(40 \mathrm{~g})$, and Tween $80(1.0 \mathrm{~g})$ than the levels A1, B2, C2 and D2 (Experimental run L2). Whereas, minimum percent TPH reduction of $86.88 \%$ was observed with the use of combination of the levels A3, B3, C2, and D1 (Experimental run L9) which are: organic fertilizer (40 g), slow release inorganic NPK fertilizer ( $5 \mathrm{~g})$, commercial activated carbon (30 g) and Tween 80 (1.0 g). However, based on the mean Signal to Noise $(\mathrm{S} / \mathrm{N})$ ratio (using the formula highest-is-best) which has been determined for each level of the significant factors (Table 9), levels A2, B2, C2, and D2 are chosen as the optimum set of levels for the studied factors to maximize the percent TPH reduction (Figure 2). Furthermore, theoretical numerical optimization technique based on desirability function (a tool in Design Expert version 10) was also carried out to predict or determine the workable optimum amendment agents' conditions for the WECO-marine water bioremediation process. The predicted optimum values of organic fertilizer (factor A), slow release inorganic NPK fertilizer (factor B), commercial activated carbon (factor $\mathrm{C}$ ) and Tween 80 (factor D) were found to be $30 \mathrm{~g}$ (A2), $4 \mathrm{~g}$ (B2), $30 \mathrm{~g}$ (C2) and $1.5 \mathrm{~g}$ (D2), respectively, to achieve maximum 98.88\% TPH reduction (crude oil biodegradation); while desirability was 1.000 for the experiment (Figure 3). This is also in agreement with the optimum set of levels obtained from the mean $\mathrm{S} / \mathrm{N}$ ratio analysis
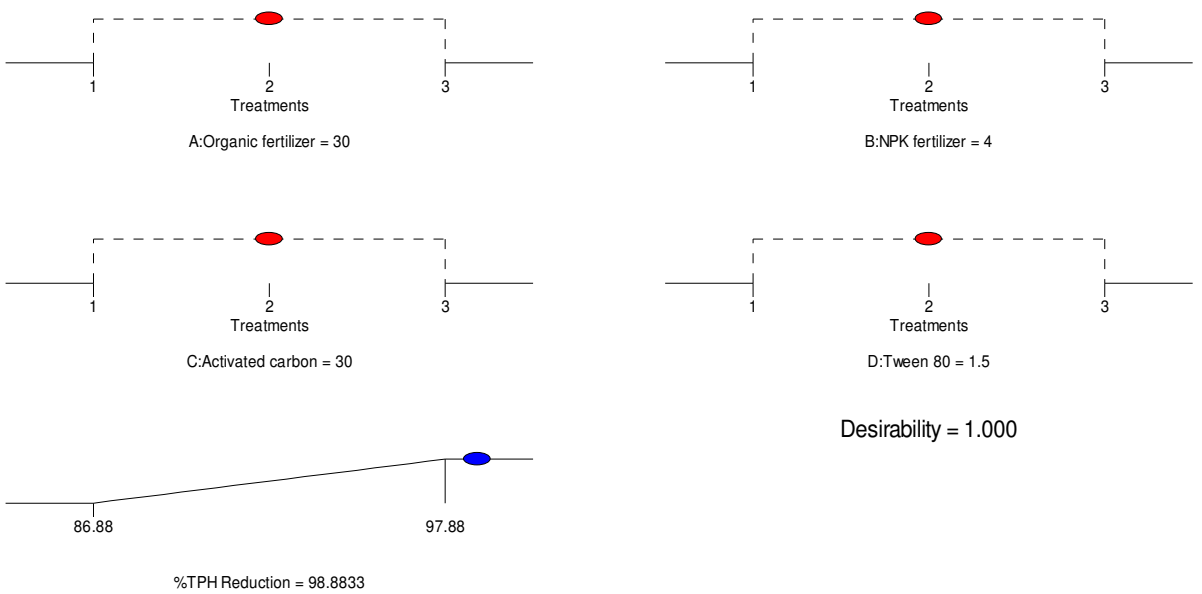

Desirability $=1.000$

Fig 3: Plot of desirability for optimization of crude oil biodegradation

After the determination of the optimum conditions and predicting the response under these conditions as shown in Figure 3, a confirmatory or validation experiment was designed and performed using the predicted optimum levels of the studied factors. The results are presented in Table 11.

Table 11: Confirmatory experimental results

\begin{tabular}{lll}
\hline & \multicolumn{2}{c}{ Optimal Process Parameters } \\
\cline { 2 - 3 } & Predicted & Experimental \\
\hline Level & A2B2C2D2 & A2B2C2D2 \\
$\%$ TPH Reduction & 98.88 & 98.25 \\
S/N (dB) & 5.06 & 5.05 \\
\hline
\end{tabular}

Errors between predicted and actual experimental values were calculated according to Eq. (6) (Agarry and Ogunleye, 2012a).

$$
\text { Error }=\frac{\text { Actual Value }- \text { Predicted Value } \times 100}{\text { Actual Value }}
$$


As presented in Table 11, in the optimized condition, $98.25 \%$ of TPH reduction was achieved having a mean $\mathrm{S} / \mathrm{N}$ ratio of $5.05 \mathrm{~dB}$. The percentage error between the predicted and actual values was found to be -0.64 . The results indicated that there was no significant difference between the predicted and actual values obtained from confirmatory or validation experiment.

Conclusion: Amendment agents considered in this study has effective potential application as a tool for combined adsorption-biostimulation strategy in the remediation of crude oil contaminated aquatic environment. Taguchi orthogonal design of experiment has effective application in the optimization of amendment agents and crude oil biodegradation. Crude oil has a very high biodegradation half-life, thus, its presence in the aquatic environment can be very persistent and its remediation using combined adsorptionbiostimulation strategy can effectively be described by a first-order kinetic model.

\section{REFERENCES}

Adesodun, JK; Mbagwu, JSC (2008). Biodegradation of waste-lubricating petroleum oil in a tropical alfisol as mediated by animal droppings. Bioresour. Technol. 99(13): 5659-5665.

Agarry, SE; Aremu, MO; Aworanti, OA (2013). Kinetic modelling and half-life study on enhanced soil bioremediation of bonny light crude oil amended with crop and animal-derived organic wastes. J. Pet Environ. Biotechnol. 4: 137.

Agarry, SE; Oghenejoboh, KM; Solomon, BO (2015). Kinetic modelling and half- life study of adsorptive bioremediation of soil artificially contaminated with bonny light crude oil. J. Ecol. Eng. 16 (3): 1-13.

Agarry, SE; Ogunleye, OO (2012a). Box-behnken designs application to study enhanced bioremediation of soil artificially contaminated with spent engine oil using biostimulation strategy. Int. J. Energy and Environ. Eng., 3: 3134.

Agarry, SE; Ogunleye, OO (2012b). Factorial designs application to study enhanced bioremediation of soil artificially contaminated with weathered Bonny light crude oil through biostimulation and bioaugmentation strategy. J. Environ. Protection 3: 748-759.

Agarry, SE; Owabor, CN; Yusuf, RO (2010). Bioremediation of Soil Artificially Contaminated with Petroleum Hydrocarbon Oil Mixtures: Evaluation of the Use of Animal Manure and Chemical Fertilizer. Bioremediation J. 14: 189195.

Agarry, SE; Owabor, CN; Yusuf, RO (2012). Enhanced Bioremediation of Soil Artificially Contaminated with Kerosene: Optimization of Biostimulation Agents through Statistical Experimental Design. J. Pet Environ. Biotechnol. 3: 120.

Agarry. SE; Ogunleye, OO (2015). Bioadsorption of 2,6-Dichlorophenol from aqueous solution onto plantain and pineapple peels mixture used as adsorbent: optimization studies based on Taguchi method, batch equilibrium, and kinetic modelling. Chem. Mater. Res. 7 (3): 1 - 15.

APHA (2005). Standard Methods for Examination of water and wastewater. American Public Health Association, Washington D.C.

Avramova, T; Sotirova, A; Galabova, D; Karpenko, E (2008). Effect of Triton X-100 and rhamnolipid PS-17 on the mineralization of phenanthrene by Pseudomonas sp. cells. Int. Biodeterior. Biodegrad. 62: 415-20.

Barrios San Martín, Y (2011). Bioremediation: a tool for the management of oil pollution in marine ecosystems. Biotecnología Aplicada, 28 (2): 6976.

Bejarano, AC; Michel, J (2010). Large-scale risk assessment of polycyclic aromatic hydrocarbons in shoreline sediments from Saudi Arabia: environmental legacy after twelve years of the Gulf war oil spill. Environ Pollut. 158: 15611569.

Bremner, JM; Mulvaney, CS (1982). Total nitrogen determination. In: Method of Soil Analysis, (Page, A. L., Miller, R. H., and Keeney, D. R., Eds.), American Society of Agronomy, Madison, WI. p. 595.

Cappello, S; Calogero, R; Santisi, S; Genovese, M; Denaro. R; Genovese, L; Giuliano, L; Mancini, G; Yakimov, MM (2015). Bioremediation of oil polluted marine sediments: A bio-engineering treatment. Int. Microbiol. 18: 127-134.

Castorena-Cortés, G; Roldán-Carrillo, T; ZapataPeñasco, I; Reyes-Avila, J; Quej-Aké, L; MarínCruz, J; Olguín-Lora, P (2009). Microcosm assays and Taguchi experimental design for treatment of oil sludge containing high concentration of hydrocarbons. Bioresour. Technol. 100: 5671-5677. 
Chaillan, F; Chaineau, CH; Point, V; Saliot, A; Oudot, J (2006). Factors inhibiting bioremediation of soil contaminated with weathered oils and drill cutting. Environ. Pollut. 144(1): 255-265.

Chaineau, CH; Rougeux, G; Yepremian, C; Oudot, J (2005). Effects of nutrient concentration on the biodegradation of crude oil and associated microbial populations in the soil. Soil Biol. Biochem. 37(8): 1490-1497.

Chien, HY; Kao, CM; Jou, CJ; Yang, PY; Huang, CC (2008). Application of enhanced bioremediation to clean up diesel-oil contaminated soils: Laboratory microcosm study. J. Biotechnol. 136: S682.

Chikere, CB; Okoye, AU; Okpokwasili, GC (2016). Microbial community profiling of active oleophilic bacteria involved in bioreactor-based crude-oil polluted sediment treatment. J. Appl. Environ. Microbiol. 4 (1): 1-20.

Couto, MNPFS; Monteiro, E; Vasconcelos, MTSD (2010). Mesocosm trials of bioremediation of contaminated soil of a petroleum refinery: comparison of natural attenuation, biostimulation and bioaugmentation, Environ. Sci. Pollut Res. 17: 1339-1346.

Cruickshank, R; Duguid, JP; Marimon, BP; Swain, RW (1980). Medical Microbiology, 12th ed., Vol. 2. Edinburgh, London: Churchill Livingstone.

Das Mohapatra, PK; Maity, C; Rao, RS; Pati, BR; Mondal, KC (2009). Tannase production by Bacillus licheniformis KBR6: Optimization of submerged culture conditions by Taguchi DOE methodology. Food Res. Int. 42: 430 - 435.

Elmahdi, AM; Aziz, HA; El-Gendy, NS; Amr, SSA; Nassar, HN (2014). Optimization of Libyan crude oil biodegradation by using solid waste date as a natural low-cost material. J Bioremed Biodeg. 5: 252.

Esme, U (2009). Application of Taguchi method for the optimization of resistance spot welding process. The Arabian J. Sci. Eng. 34 (2B): 519528.

Garcia-Delgado, C; D’Annibale, A; Pesciaroli, L; Yunta, F; Crognale, S; Petruccioli, M; Eymar, E (2015). Implications of polluted soil biostimulation and bioaugmentation with spent mushroom substrate (Agaricus bisporus) on the microbial community and polycyclic aromatic hydrocarbons biodegradation. Sci. Total Environ. 508: $20-28$.

Gertler, C; Gerdts, G; Timmis, KN; Golyshin, PN (2009). Microbial consortia in mesocosm bioremediation trial using oil sorbents, slowrelease fertilizer and bioaugmentation. FEMS Microbiol. Ecol. 69: 288-300.

Ghosh, U; Luthy, RG; Cornelissen, G; Werner, D; Menzie, CA (2011). In-situ Sorbent Amendments: A New Direction in Contaminated Sediment Management. Environ. Sci. Technol. 45: 1163- 1168 .

Hamzah, A; Md Salleh, SN; Wong, KK; Sarmani, S (2016). Nutrient amendments of inorganic fertiliser and oil palm empty fruit bunch and their influence on bacterial species dominance and degradation of the associated crude oil constituents. Soil and Sediment Contam.: An Int. J. DOI:10.1080/15320383.2016.1124834

Hassanshahian, M; Emtiazi, G; Caruso, G; Cappello, S (2014). Bioremediation (bioaugmentation/biostimulation) trials of oil polluted sea water: A mesocosm simulation study. Marine Environ. Res. 95: 28 - 38.

Hazen, TC; Prince, RC; Mahmoudi, N (2016). Marine oil biodegradation. Environ. Sci. Technol. 50: 2121-2129

Hidayat, A; Tachibana, S (2013). Crude oil and noctadecane degradation under saline conditions by Fusarium sp., F092. J. Environ. Sci. Technol. 6: $29-40$.

Holt, JG; Kreig, NR; Sneath, PHA; Staley, JT; Williams, ST (1994). Bergey's Manual of Determinative Bacteriology. 9th Edn. Lippincott Williams and Wilkins. Baltimore, USA.

Joo, H; Ndegwa, PM; Shoda, M; Phae, C (2008). Bioremediation of oil-contaminated soil using Candida catenulata and food waste. Environ. Poll. 156: 891-896.

Knezevich, V; Koren, O; Ron, EZ; Rosenberg, E (2007). Petroleum Bioremediation in Seawater Using Guano as the Fertilizer. Bioremediation J. 10 (3): 83-91.

Koh, MKP; Sun, J; Liu, S-Q (2013). Optimization of L-methionine bioconversion to aroma-active methionol by Kluyveromyces lactis using the Taguchi method. J. Food Res. 2(4): 90-100.

Kuhan, RC; Gupta, R (2009). Biological remediation of petroleum contaminate. In: A. Singh R.C. 
Kuhan O.P. Ward (Eds.), Soil Biology, Advances in Applied Bioremediation, Springer-Verlag, Berlin/ Heidelberg, pp. 73-186

Kulkarni S.V. (2014). Bioremediation of Petroleum Hydrocarbon Polluted Sites for the Conservation of Soil Microbial Diversity. Doctoral Thesis Submitted To University Of Pune, India.

Kumar, SV; Pai, KV; Narayanaswamy, R; Sripathy, M (2013). Experimental optimization for $\mathrm{cu}$ removal from aqueous solution using neem leaves based on Taguchi method. Int. J. Sci. Environ. Technol. 2 (1): 103-114.

Kumari, B; Singh, SN; Singh, DP (2016). Induced degradation of crude oil mediated by microbial augmentation and bulking agents. Int. J. Sci. Technol. 13 (4): 1029 - 1042.

Lai, C-C; Huang, YC; Wei, Y-H; Chang J-S (2009). Biosurfactant-enhanced removal of total petroleum hydrocarbons from contaminated soil. J. Hazard. Mater. 167: 609 - 614.

Latinwo, GK; Agarry, SE (2015). Kinetic Modelling of bioremediation of water contaminated with Bonny light crude oil using biostimulationbioaugmentation agent. Universal J. Environ. Res. Technol. 5 (4): 188-200

Mandal, A; Kar, S; Dutta, T; Pati, BR; Mondal, KC; Das Mohapatra, PK (2015). Parametric optimization of submerged fermentation conditions for xylanase production by Bacillus cereus BSA1 through Taguchi methodology. Acta Biol. Szeged 59(2): 189-195.

Mao, X; Jiang, R; Xiao, W; Yu, J (2015). Use of surfactants for the remediation of contaminated soils: A review. J. Hazard. Mater. 285: 419-435.

Matthies, M; Witt, J; Klasmeier, J (2008). Determination of soil biodegradation half-lives from simulation testing under aerobic laboratory conditions: a kinetic model approach. Environ. Poll. 156: 99 - 105.

McLean, EO (1982). Soil pH and lime requirement. In: Methods in Soil Analysis: Chemical and Microbiological Properties Part II, (Black, C. A., Ed.), American Society of Agronomy, Madison, WI.

Mehta, PK; Bhatia, SK; Bhatia, RK; Bhalla, TC (2016). Enhanced production of thermostable amidase from Geobacillus subterraneus RL-2a MTCC 11502 via optimization of physicochemical parameters using Taguchi DOE methodology. 3 Biotech 6: 66-77.
Meynet, P; Hale, SE; Davenport, RJ; Cornelissen, G; Breedveld, GD; Werner, D (2012). Effect of activated carbon amendment on bacterial community structure and functions in a PAH impacted urban soil. Environ. Sci. Technol. 46L: 5057-5066.

Mohajeri, L; Aziz, HA; Isa, MH; Zahed, MA; Mohajeri, S (2013). Effect of remediation strategy on crude oil biodegradation kinetics and half-life times in shoreline sediment samples. Int. J. Mar. Sci. Eng. 3 (2): 99-104.

Nandal, P; Ravella, SR; Kuhad, RC (2013). Laccase production by Coriolopsis caperata RCK2011: Optimization under solid state fermentation by Taguchi DOE methodology. Sci. Rep. 3: 1386.

Nelson, DW; Sommers, LE (1982). Determination of organic carbon. In: Method of Soil Analysis, Vol. 2, (Page, A. L., Miller, R. H., and Keeney, D. R., Eds.), American Society of Agronomy, Madison, WI. p. 539.

Nikolopoulou, M; Pasadakis, N; Norf. H; Kalogerakis, N (2013). Enhanced ex-situ bioremediation of crude oil contaminated beach sand by supplementation with nutrients and rhamnolipids. Marine Poll. Bull. 77: 37 - 44.

Obiakalaije, UM; Makinde, OA; Amakoromo, ER (2015). Bioremediation of Crude Oil Polluted Soil Using Animal Waste. Int. J. Environ. Bioremed. Biodegrad. 3 (3): 79-85.

Olsen, SR; Sommers, LE (1982). Determination of available phosphorus. In: Method of Soil Analysis, Vol. 2, (Page, A. L., Miller, R. H., and Keeney, D. R., Eds.), American Society of Agronomy, Madison, WI. p. 403.

Padayachee, D; Lin, J (2011). The effect of fertilizer amendment on diesel biodegradation in contaminated soils. Afri. J. Microbiol. Res. 5(14): 1729-1739.

Peace G. S. (1993). Taguchi Methods: A Hands-on Approach. New York: Addison Wesley.

Ravanipour, M, Kalantary, RR; Mohseni-Bandpi, A; Esrafili, A; Farzadkia, M; Hashemi-Najafabadi S (2015). Experimental design approach to the optimization of PAHs bioremediation from artificially contaminated soil: application of variables screening development. J. Environ. Health Sci. Eng. 13: 22-31. 
Rosenberg, E; Legmann, R; Kushmaro, A; Adler, E; Abir, H; Ron, EZ (1996). Oil bioremediation using insoluble nitrogen source. J. Biotechnol. 51: 273-278.

Roy, RK (2001). Design of Experiments Using the Taguchi Approach: 16 Steps to Product and Process Improvement, 1st edn. John Wiley \& Sons, New York.

Semenyuk, NN; Yatsenko, VS; Strijakova, ER; Filonov, AE; Petrikov, KV; Zavgorodnyaya, Yu.A; Vasileya, GK (2014). Effect of activated charcoal on bioremediation of diesel fuelcontaminated soil. Microbiology 83 (5): 589 598.

Tagger, S; Bianchi, A; Juillard, M; LePetit, J; Roux, B (1983). Effect of microbial seeding of crude oil in seawater in a model system. Marine Biol. 78: 13-20.

Thavasi, R; Jayalakshmi, S; Banat, IM (2011). Effect of biosurfactant and fertilizer on biodegradation of crude oil by marine isolates of Bacillus megaterium, Corynebacterium kutscheri and Pseudomonas aeruginosa. Bioresource Technol. 102(2): 772-778.

Tripathi, AD; Srivastava, SK (2011). Novel approach for optimization of fermentative condition for Polyhydroxybutyrate (PHB) production by Alcaligenes sp. using Taguchi (DOE) methodology. Afri. J. Biotechnol. 10(37): 72197224.

Tsai, TT; Kao, CM; Surampalli, RY; Chien, HY (2009). Enhanced Bioremediation of Fuel-Oil Contaminated Soils: Laboratory Feasibility Study. J. Environ. Eng. 135: 845-853.
Umanu, G; Nwachukwu, SCU; Olasode, OK (2013). Effects of cow dung on microbial degradation of motor oil in lagoon water. G.J.B.B. 2 (4): 542548.

Vasilyeva, GK; Strijakova, ER; Shea, PJ (2006). Use of activated carbon for soil bioremediation. Soil and Water Pollution Monitoring, Protection and Remediation, pp. 309-323.

Xu, Y; Lu, M (2010). Bioremediation of crude oilcontaminated soil: comparison of different biostimulation and bioaugmentation treatments. J. Hazard. Mater. 183: 395 - 401.

Yveline, LD; Frederick, J; Pierre, D; Michael, G; Jean, CB; Gilbert, M (1997). Hydrocarbon balance of a site which had been highly and chronically contaminated by petroleum Wastes of refinery from 1956 to 1997. Mar. Pollut. Bull. 22: $103-109$.

Zahed, MA; Abdul Aziz, H; Isa, MH; Mohajeri, L; Mohajeri, S; Kutty, SRM (2011). Kinetic modeling and half-life study on bioremediation of crude oil dispersed by Corexit 9500. J. Hazard Mater. 185: 1027-1031.

Zhou, J; Wu, D; Guo, D (2010). Optimization of the production of thiocarbohydrazide using the Taguchi method. J. Chem. Technol. Biotechnol. 85(10): 1402-1406.

Zhu, H; Aitken, MD (2010). Surfactant-enhanced desorption and biodegradation of polycyclic aromatic hydrocarbons in contaminated soil. Environ. Sci. Technol. 44 (19): 7260 - 7265. 